\title{
GPS ve Ps-Insar Yöntemleri Kullanılarak Koyulhisar (Sivas) Heyelanlarının İzlenmesi: İlk Sonuçlar
}

\author{
Kemal Özgür HASTAOĞLU ${ }^{1 *}$, Fatih POYRAZ ${ }^{1}$, Tarık TÜRK ${ }^{1}$, Fikret KOÇBULUT ${ }^{2}$, Uğur \\ ŞANLI ${ }^{3}$, Ișik YILMAZ ${ }^{2}$, Füsun BALIK ȘANLI ${ }^{3}$, Ramazan Alper KUÇAK ${ }^{1}$, Mehmet \\ DEMIREL $^{2}$, Önder GÜRSOY ${ }^{1}$, Hüseyin DUMAN ${ }^{1}$ \\ ${ }^{1}$ Cumhuriyet Üniversitesi, Geomatik Mühendisliği Bölümü, 58140 Sivas \\ ${ }^{2}$ Cumhuriyet Üniversitesi, Jeoloji Mühendisliği Bölümü, 58140 Sivas \\ ${ }^{3}$ Yıldız Teknik Üniversitesi, Harita Mühendisliği Bölümü, 34330 İstanbul
}

Geliş tarihi/Received 29.11.2013

Düzeltilerek geliş tarihi/Received in revised form 22.01.2014

Kabul tarihi/Accepted 14.02.2014

$\ddot{O}_{z e t}$

PS-InSAR tekniği son yıllarda genellikle, deprem nedeni ile oluşan deformasyonların, volkanik alanlardaki yer değişimlerinin ve hidrolojik, jeolojik, madencilik ya da şehir alanlarında oluşan çökmelerin belirlenmesinde kullanılmaktadır. Ancak heyelanların hareketlerinin belirlenmesinde belki de göreli olarak yeni bir yöntem olması nedeniyle çok sık kullanımı söz konusu olmamıştır. Buna karşın az da olsa yapılmış bu amaçlı çalışmalarda heyelan hareketlerinin izlenmesinde PSInSAR yönteminin başarılı olacă̆ı görülmektedir. Gerçekleştirilen bu çalışmanın temel amacı modern uzaysal yöntemler olan PS-InSAR ve GPS yöntemlerini kullanilarak mevcut alansal deformasyonun belirlenmesidir.

Projenin bir diğer amacı da Sivas ili Koyulhisar ilçesindeki mevcut kaymanın alansal olarak belirlenmesi ve bu kaymaya neden olay faktörlerin belirlenmesinin yanısıra ileriye yönelik önlemlerin alınmasını sağlamaktır. Aynı bölgede daha önce gerçekleştirilen çalışmalarda ilçe merkezinde bir kayma tespit edilmiştir. Ancak sadece tek bir noktada belirlenen bu kaymanın ne kadar bir alanda etkili olduğu ve kaymanın ana sebepleri belirlenememiştir. Bu amaçla bu proje kapsamında, eski heyelan kütlesi ve ilçe merkezinde hem GPS yöntemiyle hem de uzay tabanlı radar görüntülerinin değerlendirilmesi yöntemiyle tüm çalışma alanı üç boyutlu olarak modellenerek alansal deformasyon belirlenecektir. Bu yöntemlerle elde edilen kayma miktarları ile meteorolojik veriler (yağış miktarl, sıcaklık, yer altı su seviyesi) arasındaki ilişki incelenerek kaymanın sebepleri araştırılacaktır. Tüm bu jeodezik verilerin yanısıra bölgeye ait jeolojik ve jeofiziksel verileri içeren Afet Bilgi Sistemi (ABS) yardımı ile bölgeye ait risk analizleri gerçekleştirilecektir. Bu sayede Ilç̧edeki mevcut durum tam olarak belirlenerek ileriye yönelik doğal afetlere karşı alınacak önlemler için bir altlık oluşturulacaktır.

Bugüne kadar projenin ilk 1.5 yıllık çalışması tamamlanmış ve ilk sonuçlar elde edilmeye başlanmıştır. Bu çalışmada da proje hakkında bilgi verilerek, özellikle GPS ve PS_InSAR değerlendirmelerine ilişkin ilk sonuçlar paylaşılacaktır.

Anahtar Kelimeler: GPS, PS-InSAR, Heyelan

\footnotetext{
$1^{*}$ Kemal Özgür HASTAOĞLU, hastaoglukemal@gmail.com, Tel: (0346) 2191010
} 


\title{
Monitoring of Koyulhisar (Sivas) Landslides with GPS and PS-Insar: First Results
}

\begin{abstract}
Recently PS-InSAR method is generally used to determine deformations caused by earthquake, movements in volcanic areas, subsidence in hydrological, geological, mining or urban areas. However this method is not used so often in detemining the movements of landslides perhaps because of being a relatively new method. But it is seen in the few studies done for this aim that PSInSAR method can be succesful in monitoring landslide movements. The main purpose of this proposed project is to determine the existing areal deformation by using modern and spatial PSInSAR and GPS methods.

Besides that another aim of the project is to identificate available motion as territorial and to determine the factors that cause this motion in Koyulhisar town of Sivas, it is provided to take precautions for the future. A motion in the center of the town has been found by the studies conducted previously in the same area. However, how this motion determined only a single point is effected an area and the main causes of the motion have not identified. For this purpose, in this project, areal deformation will be determined by modeling as a three-dimensional with both the GPS method and the method of assessment of space-based radar images at the entire workspace in the center of the town and old landslide mass. The causes of the motion will be investigated by examining the relationship between Meteorological datas (rainfall, temperature, ground water level) and the motion amounts obtained by these methods. In addition to all these geodetic datas, the risk analyzes of the region will be carried out by the Disaster Information System (DIS) containing the geological and geophysical datas of the region. In this way, a basis for precautions to be taken against prospective natural disasters will be established by determining fully the present situation of the town prospectively.

Up to date, the first 1.5 years studies of the project were completed and the first results have been obtained. In this study, by giving information about the project, especially the first results of GPS and PS_InSAR evaluations will be shared.
\end{abstract}

Keywords: GPS, PS-InSAR, Landslide

\section{Giriş}

Heyelan hareketinin detaylı analizi, konumların üç boyutta belirlenmesini gerektirir (Malet v.d., 2002; Dercourt, 2000). GPS sistemi, faz ölçüleri kullanmak suretiyle mm duyarlıkta nokta konumlarını üç boyutlu olarak aynı anda belirlemektedir. $\mathrm{Bu}$ duyarlılığa sahip olan GPS küçük ve yavaş yer değişimi gösteren heyelanların izlenmesi için de rahatlıkla kullanılabilir (Coe v.d. 2003; Malet v.d., 2002; Dercourt, 2000; Gili v.d., 2000; Brunner, 1997;1994; Bayrak, 2003).

Heyelan sahasındaki alansal deformasyonları incelemek amaciyla, hava ya da yersel Fotogrametrinin yanı sıra uydu görüntüleri yardımıyla nokta koordinatları, eş yükseklik haritaları ve sayısal yükseklik modelleri elde edilebilmektedir. Heyelanların izlenmesinde özellikle son yıllarda ölçme robotları ve INSAR tekniği de oldukça yaygın olarak kullanılmaktadır. (Coe v.d. 2003; Malet v.d., 2002; Dercourt, 2000; Gili v.d., 2000).

InSAR modern bir ölçme tekniğidir ve yer yüzeyindeki günlük ya da yıllar süren değişimleri mm hassasiyetinde bir doğrulukla güvenilir şekilde ölçebilmektedir (Gens ve van Genderen, 1996; Gens,1998). Kompleks radar sinyallerinin faz bileşenlerinin InSAR tekniğine uygun olarak analiz edilmesi sonucunda yeryüzünün 3 boyutlu bilgilerine ulaş1labileceği konusu 1960'lı y1llara dayanmaktadır. 1986 yılına kada Ancak deformasyon nedeni ile oluşan yerkabuğu hareketlerinin saptanmasinda diferansiyel interferometri adı verilen DInSAR tekniğinden yararlanılır. Diferansiyel SAR interferometrisi (Differential Interferometric SAR), düşey yöndeki küçük ölçekli hareketlerin ölçümü için kullanılır DInSAR 
uzun zaman aralıklı alımlara rağmen konumsal olarak değişimin yakalanması ve yüzey ötelemelerinin haritalarının oluşturulmasını sağlayan tek yöntemdir. $\mathrm{Bu}$ nedenle deprem ve volkanik araştırmalar, buzul hareketleri, tektonik hareketler, maden, gaz, su, petrol kazıları nedeniyle oluşan yer çökmelerinin görüntülenmesi bu teknik ile önem kazanmıştır ve cm.nin altında doğrulukla veri elde edilir. Diferansiyel interferometride ölçülen öteleme düşey yönlü değildir, görüş doğrultusu boyunca oluşan öteleme üretilir (Bamler ve Hartl, 1998). Diferansiyel SAR interferometri tekniği, düşey yöndeki küçük ölçekli hareketlerin ölçümü için kullanılır. Bu teknik, farklı zamanlarda alınan SAR (Synthetic Aperture Radar = Sentetik Açıklıklı Radar) uydu görüntüleri kullanılarak konumsal değişimin yakalanması ve yüzey ötelemelerinin haritalarının oluşturulmasını sağlayan tek yöntemdir. $\mathrm{Bu}$ nedenle deprem ve volkanik araştırmalar, buzul hareketleri, tektonik hareketler, maden, gaz, su, petrol kazıları nedeniyle oluşan yer çökmelerinin görüntülenmesi ve izlenmesi bu teknik ile önem kazanmıştır. Ayrıca cm'nin altında doğrulukla veri elde edildiği yapılan çalışmalarla ispatlanmıştır (Massonet ve Feigl, 1998; Bamler ve Hartl, 1998; Hanssen 2005). Bazı faylarda gözlenen krip ve heyalan benzeri çok yavaş cereyan eden hareketler $(<$ $1 \mathrm{~cm})$ InSAR yöntemiyle başarıyla ortaya çıkartılabilmektedir (Burgmann vd., 1998, Burgmann vd., 2006, Çakır vd., 2005, ).

Diferansiyel SAR İnterfarometri (DInSAR), yerkabuğu hareketlerinin ölçülmesinde oldukça etkili bir yöntemdir. Ancak bu yöntemde interfarogramların hemen hemen hepsi çok büyük alanları kapsarlar bu durumda sinyallerin ilintisizleşmesine (decorrelate) ve ölçüm yapılamamasına sebep olmaktadır. Son y1llara geliştirilen PS-InSAR (Pressitent scatterer interferometry) yöntemi sayesinde bu sorun ortadan kaldırılmıştır (Sousa v.d. 2010). Sayılan güçlükleri aşmak için yine son yıllarda "Permenant Scatterers InSAR" (PSInSAR) yöntemi kullanılmaktadır (Feretti vd., 2001, Meisina vd., 2006, Colesanti vd., 2003a). Bu yöntem bir bölgede aynı çerçevede mevcut bir çok ( > 20) radar görüntüsünün olması durumunda kullanılabilmektedir. Hep aynı (permanent) yansitma özelliği gösteren hedeflerden (scatters) gelen sinyaller kullanılarak bölgede meydana gelen milimetre büyüklüğündeki değişimler alansal ve zamansal olarak tespit edilebilmektedir. Ölçümlerdeki ve hata payı istatistiksel olarak görüntü miktarı ve zamansal dağılımına bağlıdır.

Hooper vd. PS İnterferometri tekniğini farklı bir yaklaşımla ele alarak 2007 yılında yaptıkları kabuk hareketlerinin deformasyon analizinde StaMPS (Stanford Method for PS )yöntemini geliştirmişlerdir. Bu yöntem, bina gibi belirgin nesneler olsun olmasın, her arazi türünde analiz yapmak için düşük faz değişimi gösteren pikselleri bulmada interferometrik fazın mekansal korelasyonunu kullanmaktadir.

Heyelan araştırmalarında PS-InSAR tekniği yine Farina vd. (2006) tarafindan büyük hareketlerin olduğu Italya'daki Arno nehir yatağını kaplayan bir alanda kullanılmıştır. 350 çerçeve SAR (ERS1/ERS2) görüntüsü kullanılmış ve 600000 PS noktası tespit edilmiştir. Çalışmada yanı zamanda optik uydu görüntüleri de kullanılarak PS noktalarının herbiri hakkında bilgi elde edilmiştir. $\mathrm{Bu}$ çalışma ile mevcut heyelan envanterinin PS-InSAR tekniği ile güncellenebileceği ispatlanmıştır.

Yukarıda anlatılan yöntemler göz önünde bulundurulduğunda evrensel ölçekte de heyelanların alansal olarak izlenmesi için en yaygın ve en uygun yöntemin GPS, PSInSAR birlikte kullanılması olduğu anlaşılmaktadır. Halen günümüzde bilim insanları bu iki yöntemin en uygun hali ile nasıl kullanılacağı üzerine çalışmalar yapmaktadır. $\mathrm{Bu}$ projede, bu iki yöntemin birlikte kullanılmasıyla elde edilecek sonuçlar ile güncel bir tartışmaya katkı sağlanması amaçlanmaktadır. Bu iki yöntem ile elde edilen deformasyonlar dış kuvvetler (yağış miktarı, sicaklık, yer altı su seviyesi) ile ilişkilendirilerek bölge için bir erken uyarı mekanizması oluşturulması planlanmaktadır. 


\section{2. Çalışma Bölgesi}

Koyulhisar Kuzey Anadolu Fay Zonu üzerinde yer almaktadır. Bölgede yüzeyleyen kaya birimleri yaşlıdan gence doğru, Üst Santoniyen yaşlı Gökçebel, Üst SantoniyenAlt Maestrihriyen yaşlı Kızıltepe ve Kapaklı, Orta-Üst Maestrihtiyen yaşlı Aşağıkale, Üst Maestrihtiyen yaşlı İğdir, Daniyen yaşlı Şıhlar, Orta-Üst Paleosen yaşlı Yalnıztepe ve Düdenyaylası, Orta Eosen yaşlı Taşpınar, Pliyosen yaşlı Erdembaba ve PliyoKuvaterner yaşlı Koyulhisar Formasyonlarından oluşmaktadır. İlk sekiz formasyon, geç Kretase-Paleosen sırasında, volkanik yay tipi bir ortamda çökelmiş, üste doğru tane boyu artan kalın bir istif oluşturur. Eosen yaşlı Taşpınar formasyonu sığ denizel kırıntılardan oluşur. Son iki formasyon ise neotektonik dönemin ürünüdür (Toprak 1988). Bölge Kuzey Anadolu Fay Zonu üzerinde yer almaktadır. Kuzey Anadolu Fay Zonu bölgede 6-8 km. genişliğinde ve $32 \mathrm{~km}$. uzunluğunda doğrultu atımlı sağ yanal bir fay kuşağıyla temsil edilir. Bölgedeki bu kuşak Toprak (1988) tarafindan Kuzey Anadolu Ana Fayı, Koyulhisar fay takımı, Kelkit fay takımı, Şıhlar fay takımı, ve Kuruçay fay takımı olmak üzere beş fay takımına ayrılmıştır. Koyulhisar ilçe merkezini en yakından etkileyen fay takımları Şıhlar ve Koyulhisar fay takımlarıdır. (Şekil 1).

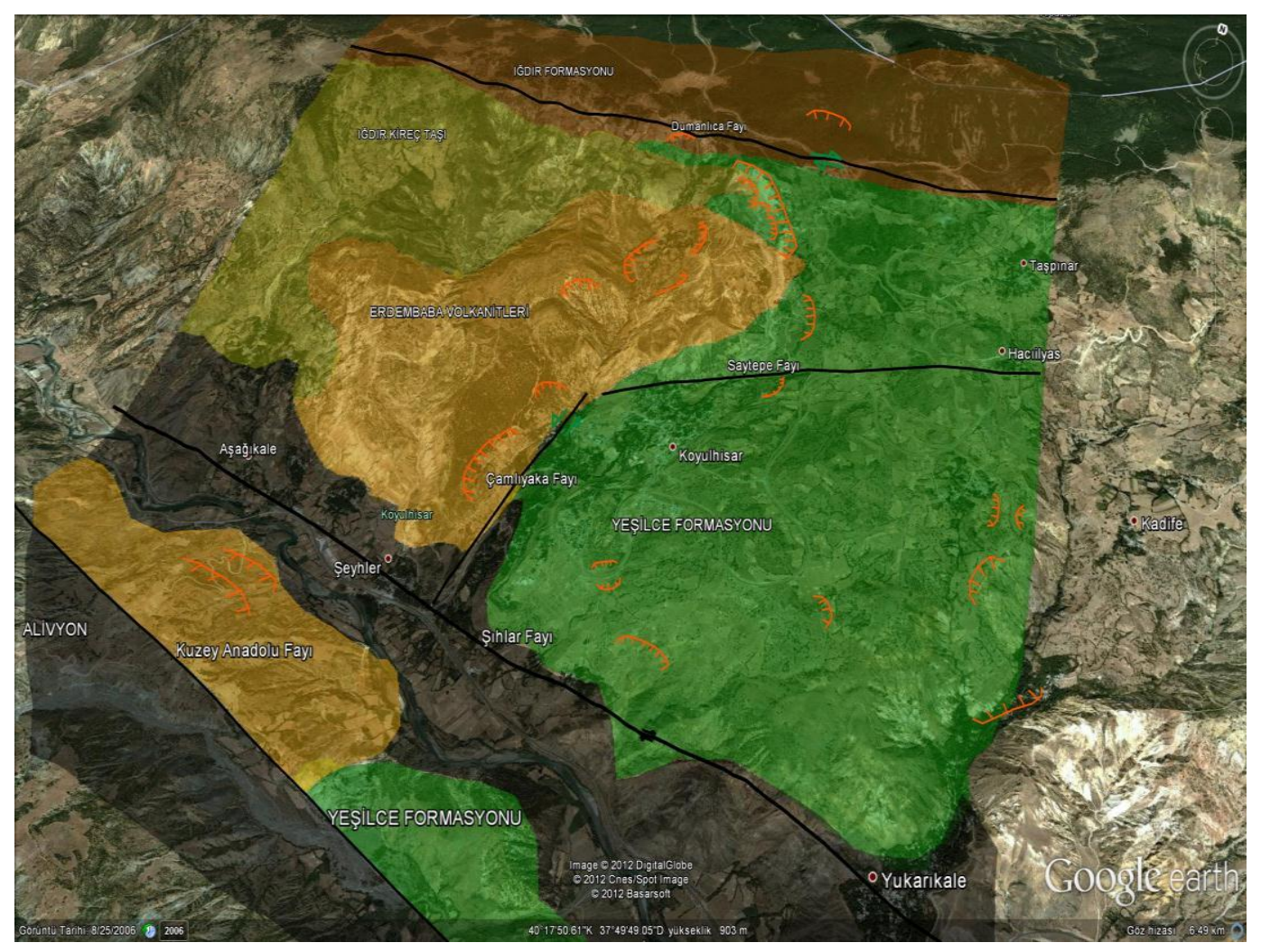

Şekil 1. Koyulhisar bölgesi jeolojik haritası (Kuzey Güney Görünümü)

Koyulhisar ilçesi, Sivas'a $180 \mathrm{~km}$ uzaklikta olup, batıda Tokat'in Reşadiye kuzeyde Ordu ilinin Mesudiye, doğuda Suşehri ve güneyde Zara ve Hafik ilçeleri ile çevrilidir. Çalıma alanın tektonik olarak aktif bir fay olan Kuzey Anadolu Fay Zonu'nda (KAFZ) yer almasi nedeni ile bölgedeki kayalar genellikle kırıklı, ezilmiş ve süreksizlikler içermektedir. Bölgedeki yüksek eğimli topografyaya da bağımlı olarak bölge içerisinde eski ve yeni birçok heyelan bulunmaktadır. $\mathrm{Bu}$ heyelanların hareket yönleri ise, genelde yerleşim alanlarını tehdit eder konumdadır (Sendir ve Y1lmaz, 2002).

Koyulhisar; KAFZ üzerinde yer alan, yüksek dağların ve sık ormanların bulunduğu bir bölgedir. $\mathrm{Bu}$ bölgenin sik sik heyelanlara 
maruz kaldığı bilinmektedir. Kaymalar genellikle ağır geçen kış mevsiminden sonra Koyulhisar'ın daha çok kuzeyinde moloz akmaları şeklinde gözlenmektedir. Yine, bu her iki heyelan da, son yılların en ağır geçen kış ve bahar mevsimlerinden sonra gelmiştir (Sendir ve Y1lmaz, 2002).

2000 yılı Temmuz ayında, 1998 yılında meydana gelen heyelanlarla ilgili çalışmalarda öngörülmüş olan yeni bir heyelan bir önceki heyelanın hemen gerisinde, daha kuzeyde meydana gelmiştir. Hem 1998 hem de 2000 yilında meydana gelen heyelanlarda gerilme çatlaklarının su ile dolu olduğu, ve kayan her kütlenin topuğunda göllerin oluştuğu gözlenmiştir. Yine, bu her iki heyelan da, son yılların en ağır geçen kış ve bahar mevsimlerinden sonra gelmiştir (Sendir v.d 2001).

Çalışma alanında, suyun temel kaynağ 1 yağmur suları olup, bu sular hidrolojik çevrimin en önemli bileşenidir. Yağışlar her mevsime dağılmakla beraber, en fazla yağış Mayıs ayında olup 64 mm'dir. En düşük yıllık ortalama yăğı̧̧ değeri 1962 yılında $265.9 \mathrm{~mm}$ ve en yüksek değer olan $575.1 \mathrm{~mm}$ ise 1983 y1lında kaydedilmiş olup. Koyulhisar ve Suşehri Meteoroloji istasyonlarından alınan 37 yıllık ortalama yağış $394.6 \mathrm{~mm}$ 'dir. (Sendir ve Y1lmaz, 2002).

\section{GPS Ölçü ve Değerlendirmeleri}

İstikşaf çalışmalarında altlık olarak Google Earth uydu görüntüleri ve Yılmaz (2009)' da belirtilen bölgeye ait jeolojik harita kullanılmıştır. Tesis edilecek GPS noktası lokasyonları belirlenirken bölgede daha önce gerçekleştirilmiş çalışmalardan faydalanılmıştır. Hastaoğlu (2009); özellikle şehir merkezinde Emniyet binasının bulunduğu bölgede ortalama yıllık $8 \mathrm{~cm}$ olmak üzere, mevcut heyelan kütlesi üzerinde ise ortalama yıllık $1.5 \mathrm{~cm}$ hareket belirlemiştir. Bunun yanı sıra gerek yöre halkı gerekse yerel yönetim tarafından özellikle Emniyet binası ve civarında gözle görülebilir deformasyonların olduğu beyan edilmiş olup, bu beyanlar Hastaoğlu (2009) tarafindan verilen bilgileri doğrulamaktadır.
$\mathrm{Bu}$ doğrultuda çalışma alanında iki farklı GPS nokta ağı planlanmıştır. Bunlardan ilki Şehir merkezindeki Emniyet Müdürlügü binası ve çevresinde yaklaşık 30 noktadan oluşan ve noktalar aras1 mesafenin 50-70 m arasinda olduğu birinci ağ ve diğeri ise tüm şehir merkezini kapsayan noktalar arası mesafelerin 100-200 m arasında değiştiği ve yaklaşık 24 noktadan oluşan ikinci ağdır. Bu GPS ağlarının yanı sıra eski heyelan kütlesi üzerine 4 ve taç kısmına 2 adet GPS noktası tesis edilmesi planlanmıştır. İki adet nokta ise heyelan sahası dışında sabit nokta olarak belirlenmiştir. $\mathrm{Bu}$ sabit noktalar belirlenirken gerekli jeolojik ve jeodezik kısitlamalara dikkat edilmiştir. $\mathrm{Bu}$ sabit noktalardan birincisi IKYK ismindeki ve çalışma sahasına yaklaşı $13 \mathrm{~km}$ uzaklıktaki TUTGA noktası olarak planlanmıştır. İkinci sabit nokta ise İlçede yeni yapılan TOKİ konutları civarında bulunan TKYK ismindeki nokta olarak planlanmıştır. Tüm bu noktalara ait Google Earth görüntüsü Şekil 2 ve $3^{\text {' }}$ de verilmektedir. Şekil 2' de sadece Eminiyet binası civarındaki $50 \mathrm{~m}$ aralıklarla tesis edilen GPS noktaları, Şekil 3' de ise Emniyet binası civarındaki noktalar dışında kalan yaklaşık 100-200 m aralılarla tesis edilen diğer noktalar görülmektedir.

GPS ölçümlerine geçilmeden önce ölçü periyotlarının tarihleri belirlenmiştir. GPS ölçüleriyle deformasyon miktarlarının tam olarak belirlenebilmesi için, çalışılacak bölgedeki deformasyonların ana nedenlerinin bilinmesi gerekmektedir. Deformasyonu tetikleyen etkiler doğrultusunda deformasyon miktarları farklı hareketler gösterebilirler. Örneğin bir mevsimsel etkide deformasyon miktarı periyodik bir salınım gösteriyorsa bu bölgede periyodik etkinin pik yaptığı aylarda ölçüm yapılması gerekmektedir. Aksi takdirde elde edilecek deformasyon miktarları yorumlanırken hata yapılabilir. Bu doğrultuda ilk olarak, literatür araştırması ile proje sahasında oluşan heyelanların ana nedenleri incelenmiştir. 


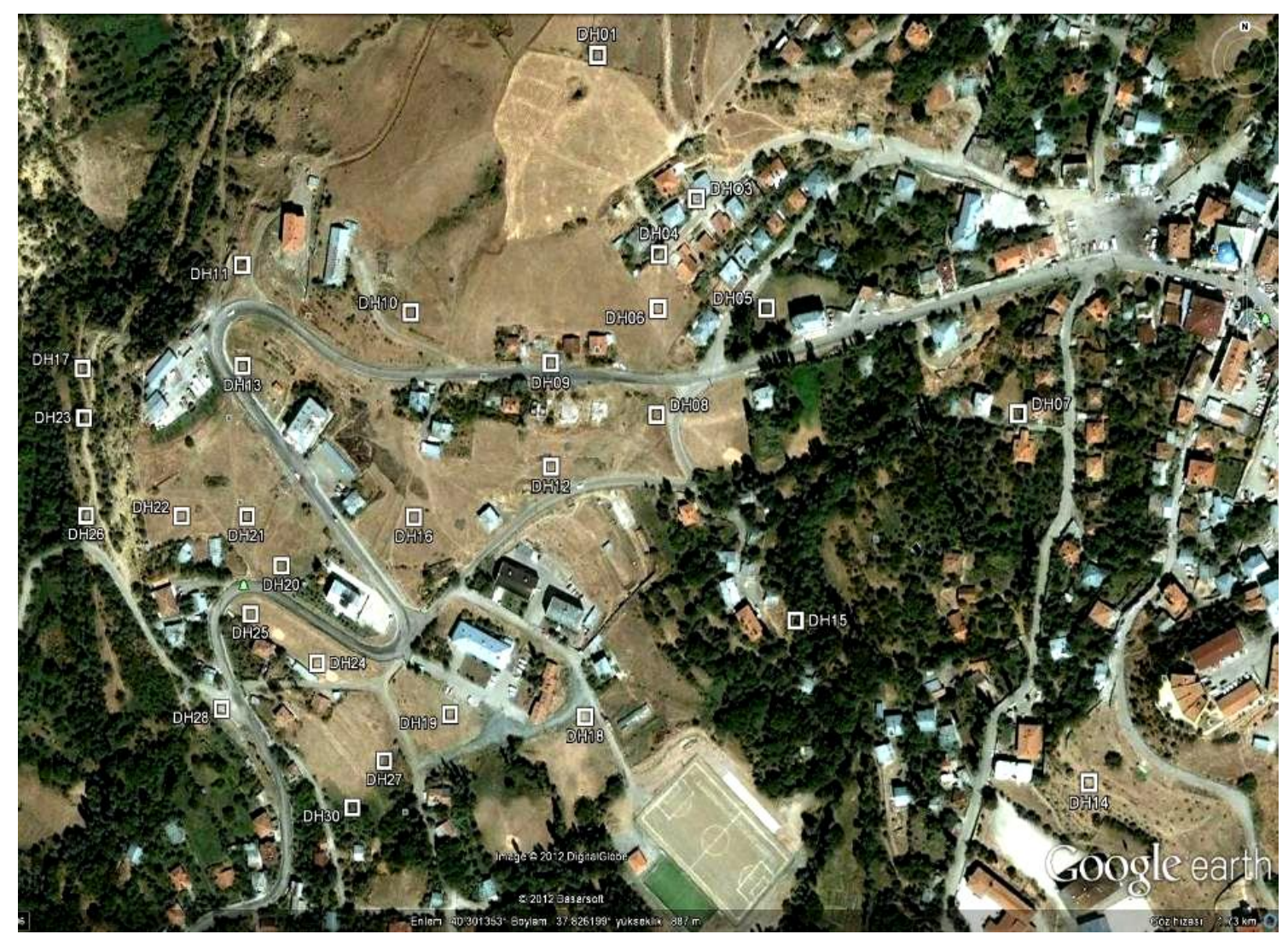

Şekil 2. Emniyet binası civarındaki $50 \mathrm{~m}$ aralıklarla tesis edilen GPS noktaları

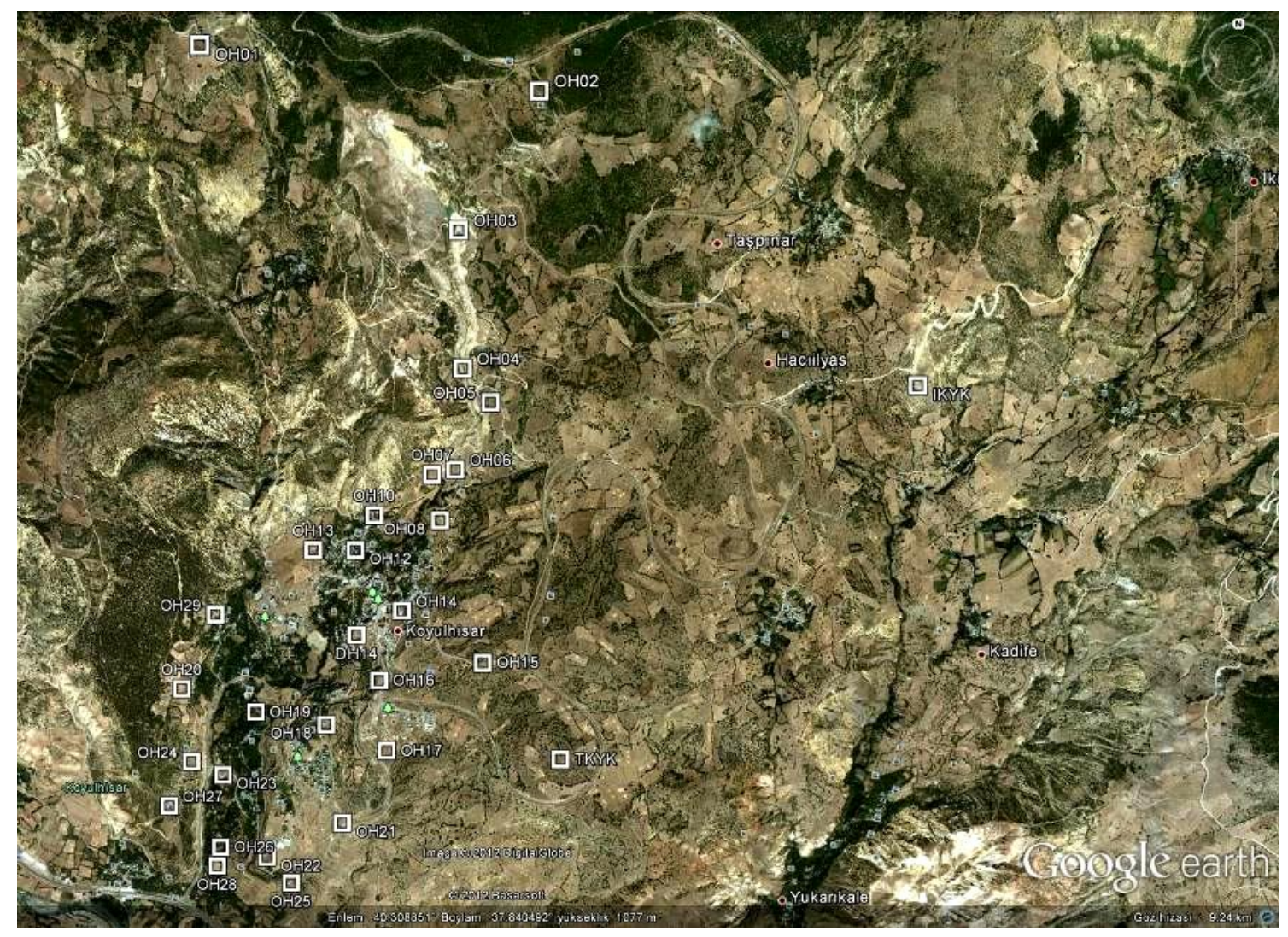

Şekil 3. Emniyet binası civarındaki noktalar dışında kalan yaklaşık 100-200 m aralılarla tesis edilen diğer noktalar 
Gerçekleştirilen çalışma sonucunda, bölgede daha önce gerçekleşen 1998 ve 2000 yıllarındaki her iki heyelanın da yoğun kar yağışı ile geçen kış mevsiminin ardından yaz aylarında gerçekleştiği görülmüştür. Hem 1998 hem de 2000 yılında meydana gelen heyelanlarda gerilme çatlaklarının su ile dolu olduğu ve kayan her kütlenin topuğunda göllerin oluştuğu gözlenmiştir. Yine, bu her iki heyelan da, son yılların en ağır geçen kış ve bahar mevsimlerinden sonra gelmiştir (Sendir ve Yılmaz, 2001). Çalışma alanında, suyun temel kaynağı eriyen kar ve yağmur suları olup, bu sular hidrolojik çevrimin en önemli bileşenidir. Özetle bölgedeki deformasyonların ana nedeninin yeraltı su seviyesindeki değişimler olduğu tespit edilmiş olup GPS ölçüm tarihleri de bu değişimler göz önüne alınarak planlanmıştır.
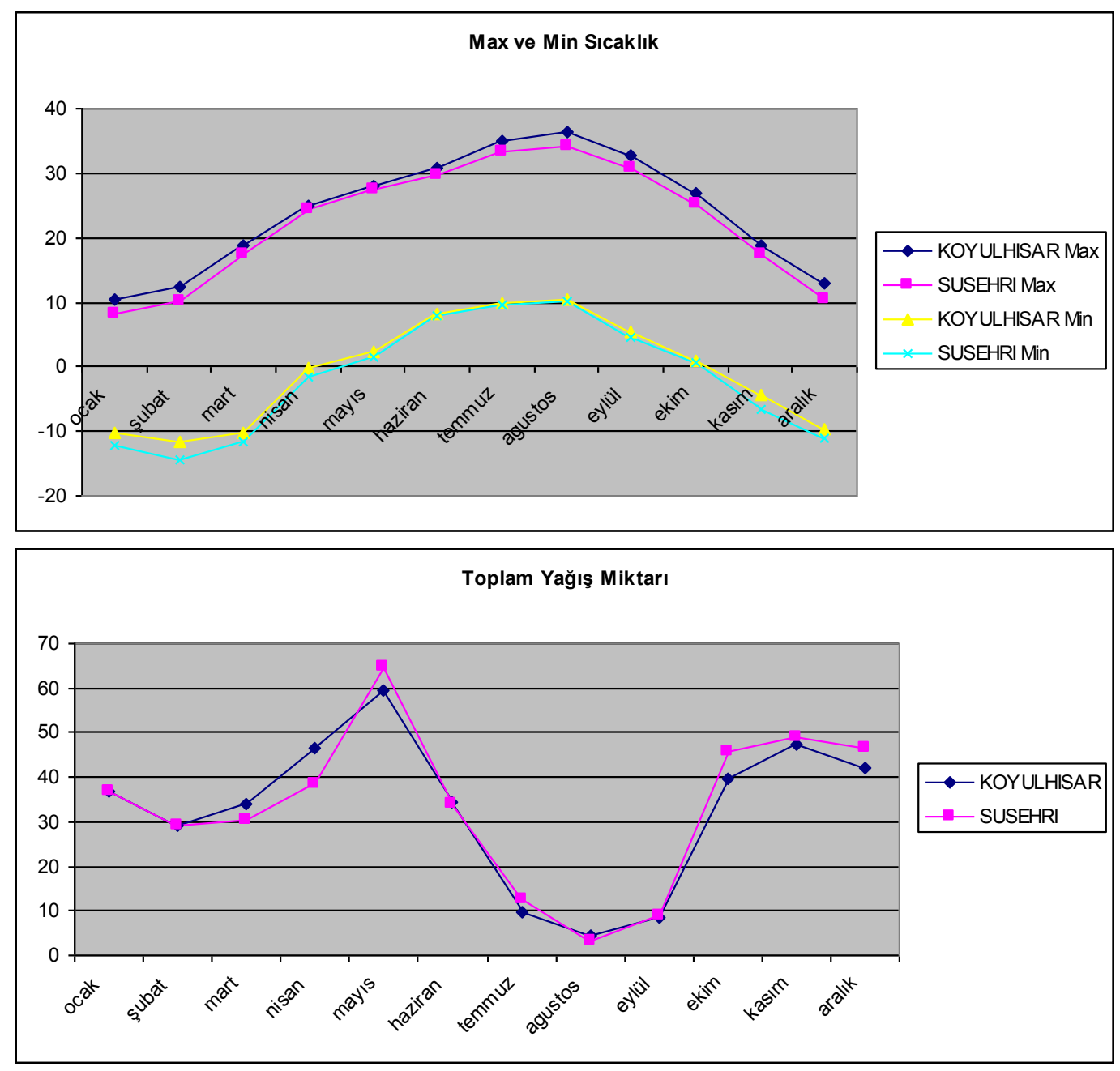

Şekil 4. Koyulhisar ilçesine ait aylara göre sıcaklık ve toplam yağıș miktarları (Sıcaklıklar derece, yağış miktarları $\mathrm{m}^{2}$ başına düşen ortalama $\mathrm{m}^{3}$ biriminde verilmiştir.)

Şekil 4 incelendiğinde sıcaklıkların NisanMayıs aylarında artışa geçtiğini, Ağustos' da maksimum değere ulaştığını ve yine EkimKasım ayında inişe geçtiğini görebiliyoruz. Yağış miktarlarının ise Nisan- Mayıs' da maksimum, Ağustos' da minimum EkimKasım'da tekrar artığını görüyoruz. Hem sıcaklıktaki hem de yağıştaki bu periyodik değişimler göz önüne alınarak ölçüm dönemleri olarak, Nisan, Ağustos, Kasım ayları tercih edilmiştir. Kasım ayından Nisan ayına kadar bölgede kar yağışı olduğu için noktalara ulaşım bu aylarda imkansız bir hal almaktadır, bu yüzden Kasım-Nisan ayları arasında bir ölçüm planlanamamıştır. Tüm bunların yanı sıra Nisan 2012' deki 1. Periyot 
GPS ölçüsünün hemen ardından Haziran 2012' de ek bir ölçü daha yapılması planlanmıştır. Bunun nedeni özellikle kar sularının nisan ayında erimesi ve bu bir aylık sürede herhangi bir deformasyon oluşup oluşmadığının anlaşılmasıdır. Özetle NisanAgustos arasındaki olası bir deformasyonun salınımını öğrenmek amacı ile haziran ayında da bir ölçü planlanmıştır.

GPS ölçüleri için Cumhuriyet Üniversitesi Geomatik Mühendisliği Bölümüne ait 6 adet Trimble 5700 marka GPS seti, 3 adet Leica GS15 marka GPS seti olmak üzere toplamda 9 adet GPS aleti kullanılmıştır. Şu ana kadar 6 periyot GPS ölçüsü gerçekleştirilmiştir. TKYK ve IKYK noktalarında günlük 12 saat diğer noktalarda 1' er saat 3 gün tekrarlı GPS gözlemleri gerçekleştirilmiştir.

GPS verilerinin değerlendirilmesinde ilk olarak günlük 12 saatlik veriye sahip heyelan sahasının dışında bulunan IKYK ve TKYK noktaları, IGS noktaları ile birlikte BERNESE 5.0 yazılımı kullanılarak değerlendirilmiş ve IKYK TKYK noktalarına ait koordinat bilgileri elde edilmiştir. Daha sonra IKYK ve TKYK noktaları sabit alınarak tüm noktalar değerlendirilmiş ve noktalara ilişkin koordinat değerleri elde edilmiştir.

\section{GPS Noktalarına ait Hız Değerlerinin Kestirilmesi}

Kalman Filtreleme yönteminde statik ve kinematik hareketler araştırılır. Bu yöntemin fark1 ve olumlu yanı düzgün ve düzgün olmayan hareketleri az sayıdaki periyot ölçü ile belirleyebilmesidir. Kalman Filtreleme yönteminde amaç önceki periyotta bilinen hareket parametrelerinden ekstrapolasyon yoluyla sonraki periyottaki hareket parametrelerinin hesaplanmasıdır (Bayrak 2003). Kalman filtre tekniği, rastgele hatalar içeren dinamik bir sisteme uygulanan en uygun parametre kestirim işlemidir (Doğan 2002).

Kalman Filtreleme Yöntemi. $t_{i-1}$ peryodun da bilinen hareket parametrelerinde oluşan durum vektörü bilgileri ve $t_{i}$ peryodun da yapılmış ölçüler yardımıyla güncel durum vektörünün tahmininde kullanılır. 3 boyutlu ağlar için konum. hız ve ivmeden oluşan hareket modeli Eşitlik 1 de verilmiştir.

$$
\begin{aligned}
& X_{j}^{(k+1)}=X_{j}^{(k)}+\left(t_{k+1}-t_{k}\right) v_{x j}+\frac{1}{2}\left(t_{k+1}-t_{k}\right)^{2} a_{x j} \\
& Y_{j}^{(k+1)}=Y_{j}^{(k)}+\left(t_{k+1}-t_{k}\right) v_{y j}+\frac{1}{2}\left(t_{k+1}-t_{k}\right)^{2} a_{y j} \\
& Z_{j}^{(k+1)}=Z_{j}^{(k)}+\left(t_{k+1}-t_{k}\right) v_{y j}+\frac{1}{2}\left(t_{k+1}-t_{k}\right)^{2} a_{z j}
\end{aligned}
$$

$X_{j}^{(k+1)}, Y_{j}^{(k+1)}, Z_{j}^{(k+1)}:_{\mathrm{j}} \quad$ noktasinın $\quad\left(\mathrm{t}_{\mathrm{k}+1}\right)$.

Periyot koordinat değeri,

$X_{j}^{(k)}, Y_{j}^{(k)}, Z_{j}^{(k)}:$

j noktasının $\left(t_{k}\right)$. Periyot

koordinat değeri,

$v_{x j}, v_{y j}, v_{z j}:{ }_{\mathrm{j}}$ noktasının $\mathrm{X}, \mathrm{Y}, \mathrm{Z}$ koordinat hiz değerleri,

$a_{x j}, a_{y j}, a_{z j}: \mathrm{j}$ noktasinın X,Y,Z koordinat ivme değerleri,

$$
\begin{aligned}
& k=1,2, \ldots \ldots \ldots . ., i \text { (i: ölçülen periyot sayısı), } \\
& j=1,2, \ldots \ldots \ldots ., n \text { (n: ölçülen nokta sayısı). }
\end{aligned}
$$

Kalman Filtrelme Yöntemi prediksiyon (prediction). süzme (filtering) ve yumuşatma (smoothing) olmak üzere üç temel aşamadan oluşmaktadır. (Cross 1990). Nokta hareket parametrelerini Kalman filtreleme yöntemiyle hesaplayabilmek için Eşitlik 1'deki denklemlerin zaman göre birinci türevi alınarak hız denklemleri ikinci türevleri alınarak ivme denklemeleri oluşturulur. Eşitlik 2 ve 3' de bu denklemlere ait matris formu verilmektedir.

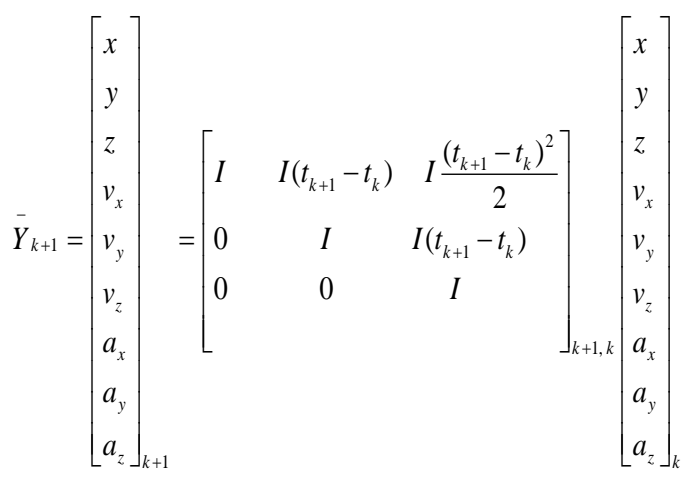


$\bar{Y}_{k+1}=T_{k+1, k} \hat{Y}_{k}$

$\bar{Y}_{k+1}:\left(\mathrm{t}_{\mathrm{k}+1}\right)$ anındaki durum vektörü, $\hat{Y}_{k}:\left(\mathrm{t}_{\mathrm{k}}\right)$ anındaki durum vektörü $T_{k+1, k}$ : prediksiyon matrisi ve $I$ : Birim matrisidir. Eşitlik 3 temel Kalman Filtreleme eşitliğidir. $\left(t_{k+1}\right)$ ve $\left(\mathrm{t}_{\mathrm{k}}\right)$ periyotları arasındaki sabit bozucu ivme $w$ olmak üzere prediksiyon denkleminde bulunan sistem gürültüleri Eşitlik 3'deki $T_{k+1, k}$ matrisinin son sütunundaki terimlerden oluşan $S$ gürültü vektörü olarak düşünülür. Bunun sonucunda prediksiyon matrisi ve kovaryans matrisi aşağıdaki gibi olur (Gülal. 1999. Bayrak 2009. Acar vd. 2008).

$\bar{Y}_{k+1}=T_{k+1, k} \hat{Y}_{k}+S_{k+1, k} w_{k}$

$Q_{\bar{Y} \bar{Y}, k+1}=T_{k+1, k} Q_{\hat{Y} \hat{Y}, k} T_{k+1, k}^{T}+S_{k+1, k} Q_{w w, k} S_{k+1, k}^{T}$

$S_{k+1, k}^{T}=\left[\begin{array}{lll}I \frac{\left(t_{k+1}-t_{k}\right)^{2}}{2} & I\left(t_{k+1}-t_{k}\right) & I\end{array}\right]$

$Q_{w w, k-1}=4\left(t_{k}-t_{k-1}\right)^{-4} Q_{S S, k-1}$

$S_{k+1, k}^{T}:\left(\mathrm{t}_{\mathrm{k}+1}\right)$ ve $\left(\mathrm{t}_{\mathrm{k}}\right)$ periyotları arasındaki gürültü vektörü,

$Q_{\hat{Y} \hat{Y}, k}: \quad\left(\mathrm{t}_{\mathrm{k}}\right)$ anında durum vektörüne ait kovaryans matrisi,

$Q_{w w, k}:\left(\mathrm{t}_{\mathrm{k}}\right)$ aninda bozucu etki ivmesinin kovaryans matrisi.

Bozucu etkilerin ivme vektörü $w$ belirsizdir ve kural olarak ölçülemez. Bu nedenle pseudo gözlem vektörü $\quad w=0$ olarak alınabilir (Bayrak 2009). k+1 periyodunda yapılmış olan ölçülere ait düzeltme denklemi Eşitlik 8 'de verilmektedir.

$l_{k+1}+v_{l, k+1}=A_{k+1} \hat{Y}_{k+1}$

Burada $l_{k+1}:\left(\mathrm{t}_{\mathrm{k}+1}\right)$ anındaki ölçüler. $v_{l, k+1}$ :düzeltme değerleri, $A_{k+1}$ : Katsayılar matrisi ve $\hat{Y}_{k+1}:\left(\mathrm{t}_{\mathrm{k}+1}\right)$ anındaki durum vektörüdür. Eşitlik 4 ve Eşitlik 8 birleştirilerek filtre aşamasının fonksiyonel ve stokastik modeli aşağıdaki gibi oluşturulur. (Acar vd. 2008. Bayrak 2009. Yalcınkaya ve Bayrak 2005).

$\left[\begin{array}{l}- \\ Y_{k+1} \\ l_{k+1}\end{array}\right]=\left[\begin{array}{l}I \\ A_{k+1}\end{array}\right] \hat{Y}_{k+1}-\left[\begin{array}{c}v_{Y_{Y, k+1}} \\ v_{l, k+1}\end{array}\right] ; \quad Q_{i}=\left[\begin{array}{ll}Q_{Y Y, k+1} & 0 \\ 0 & Q_{l l, k+1}\end{array}\right]$

Model çözülerek hareket parametreleri ve onlara ait kovaryans matrisleri hesaplanır.

$\mathrm{Bu}$ çalışmada heyelan sahasında bulunan 55 adet GPS noktası için 6 periyot GPS ölçüsü değerlendirilmiş ve koordinat değerleri elde edilmiştir. Elde edilen bu koordinat değerleri kullanılarak Eşitlik 1'de verilen 3 Boyutlu Kinematik Kalman Filtreleme Modeli yardımı ile GPS noktalarına ait h1z değerleri kestirilmiştir. $\mathrm{Bu}$ değerler Tablo 1' de sunulmaktadır.

Tablo 1 incelendiğinde özellikle Emniyet Müdürlüğü civarındaki noktalarda anlamlı kaymaların gerçekleştiği gözlenmektedir. Şekil 5 ve 6 da ise Şehir merkezinde ve Emniyet Merkezi civarında bulunan GPS noktalarına ait yatay ve düşey hız vektörleri verilmektedir.

\section{Uzay Radar Görüntülerinin Değerlendirmesi}

Uzay Radar Görüntülerinin Değerlendirilmesi işlemine ilk olarak ENVISAT uydusuna ait görüntülerin değerlendirilmesinden başlanılmıştır. Avrupa Uzay Ajansından bölgeye ait ENVISAT görüntüleri temin edilmiştir. Bölgeye ait iki adet alçalan iki adette yükselen uydu verileri bulunmaktadır bu uydulardan 78 ve 307 iz numaralı uydular alçalan uydular olup 443 ve 171 numaralı uydular ise yükselen uydulardır. Alçalan ve yükselen uydular ve SAR ölçümü temel prensibi Şekil 7'de verilmektedir. 
Tablo 1. Heyelan sahası içerisindeki noktala ait hız (cm / yıl) değerleri

\begin{tabular}{|c|c|c|c|c|c|c|c|c|c|}
\hline & \multicolumn{3}{|c|}{ Hiz } & \multicolumn{3}{|c|}{ Standart Sapma } & \multicolumn{3}{|c|}{ Test Değeri } \\
\hline & Vn & Ve & Vup & Sn & Se & Sup & Tn & Te & Tup \\
\hline DH01 & -4 & 1.5 & 3.4 & 2 & 1.8 & 2.8 & 2.1 & 0.9 & 1.19 \\
\hline DH03 & -1.2 & -0.3 & 0.7 & 2.2 & 1.9 & 3.6 & 0.6 & 0.2 & 0.19 \\
\hline DH04 & 2.5 & -0.5 & 0.4 & 2 & 1.8 & 3 & 1.2 & 0.3 & 0.12 \\
\hline DH05 & -2.4 & 0.3 & 2 & 3.3 & 2.6 & 6.2 & 0.7 & 0.1 & 0.33 \\
\hline DH06 & -2.7 & 1.6 & -1.2 & 1.9 & 1.7 & 2.8 & 1.4 & 0.9 & 0.42 \\
\hline DH07 & -2.6 & -0.3 & -0.9 & 2.5 & 2.3 & 4 & 1 & 0.1 & 0.24 \\
\hline DH08 & 0.4 & -0.6 & -3.6 & 2 & 1.8 & 3 & 0.2 & 0.3 & 1.19 \\
\hline DH09 & -0.7 & -1 & 0 & 2 & 1.7 & 3.1 & 0.4 & 0.6 & 0.02 \\
\hline DH10 & -2.5 & -0.2 & -4 & 1.8 & 1.6 & 2.7 & 1.4 & 0.1 & 1.48 \\
\hline DH11 & -1.2 & -0.2 & -0.1 & 1.9 & 1.7 & 3 & 0.6 & 0.1 & 0.03 \\
\hline DH12 & -2.9 & -1.1 & 0.5 & 2 & 1.8 & 3.1 & 1.4 & 0.7 & 0.16 \\
\hline DH13 & 0.3 & 0.6 & -2 & 1.8 & 1.5 & 2.7 & 0.2 & 0.4 & 0.72 \\
\hline DH14 & -0.8 & 0.2 & 5 & 2 & 1.8 & 3.3 & 0.4 & 0.1 & 1.49 \\
\hline DH15 & -0.5 & -0.8 & 1.9 & 2.3 & 2.1 & 3.6 & 0.2 & 0.4 & 0.52 \\
\hline DH16 & 0.6 & 1.4 & 2.5 & 1.9 & 1.6 & 2.9 & 0.3 & 0.9 & 0.87 \\
\hline DH17 & -0.4 & 0.1 & 1.4 & 2 & 1.8 & 3.1 & 0.2 & 0 & 0.45 \\
\hline DH18 & -1.3 & -1 & 8.6 & 2.1 & 1.8 & 3 & 0.6 & 0.6 & 2.84 \\
\hline DH19 & -0.2 & -0.4 & 1.7 & 1.8 & 1.6 & 2.7 & 0.1 & 0.3 & 0.64 \\
\hline DH20 & -2.8 & -1.4 & -4.8 & 1.8 & 1.7 & 2.6 & 1.5 & 0.8 & 1.81 \\
\hline DH21 & -7.3 & -1.1 & -0.5 & 1.8 & 1.6 & 2.6 & 4.1 & 0.7 & 0.21 \\
\hline DH22 & -1.5 & 0.3 & 0.8 & 1.7 & 1.5 & 2.6 & 0.9 & 0.2 & 0.31 \\
\hline DH24 & -1.6 & -0.2 & -0.6 & 1.8 & 1.6 & 2.8 & 0.9 & 0.1 & 0.2 \\
\hline DH25 & -2.7 & 0 & 0.8 & 1.8 & 1.6 & 2.8 & 1.5 & 0 & 0.3 \\
\hline DH26 & -0.1 & -0.2 & 6.4 & 2.3 & 2 & 4 & 0.1 & 0.1 & 1.59 \\
\hline DH27 & -1.6 & -0.4 & 0 & 2.1 & 1.8 & 3.1 & 0.8 & 0.2 & 0.02 \\
\hline DH28 & -1.6 & 0.2 & -1.3 & 1.8 & 1.7 & 2.7 & 0.9 & 0.1 & 0.49 \\
\hline DH29 & 1.5 & 2.9 & 4.5 & 1.8 & 1.7 & 2.8 & 0.8 & 1.7 & 1.63 \\
\hline ОН01 & 0.1 & 2 & -1.5 & 1.9 & 1.7 & 2.8 & 0.1 & 1.2 & 0.54 \\
\hline ОН02 & -1 & 1.7 & -0.9 & 1.8 & 1.6 & 2.5 & 0.6 & 1.1 & 0.35 \\
\hline ОН03 & -0.6 & 0.4 & 0.7 & 1.9 & 1.6 & 2.5 & 0.3 & 0.3 & 0.28 \\
\hline ОН04 & -0.5 & 1.3 & -6.6 & 1.7 & 1.5 & 2.3 & 0.3 & 0.9 & 2.88 \\
\hline OH05 & -0.3 & 0.7 & 4.5 & 2 & 1.6 & 2.6 & 0.2 & 0.5 & 1.72 \\
\hline ОН06 & -1.1 & 0.4 & -2.4 & 2 & 1.6 & 2.6 & 0.5 & 0.2 & 0.93 \\
\hline ОН07 & -0.9 & 0.1 & 0.3 & 1.9 & 1.7 & 3 & 0.4 & 0.1 & 0.11 \\
\hline ОН08 & -0.8 & -0.6 & 2.2 & 2 & 1.8 & 2.8 & 0.4 & 0.3 & 0.77 \\
\hline OH10 & -1.4 & 0.3 & 1.9 & 2.2 & 1.9 & 3.6 & 0.7 & 0.1 & 0.51 \\
\hline OH12 & -1.1 & 0.9 & 1.9 & 2.6 & 2.5 & 4.9 & 0.4 & 0.3 & 0.39 \\
\hline OH13 & 3.6 & -3 & -4.8 & 1.9 & 1.8 & 2.9 & 1.8 & 1.7 & 1.66 \\
\hline OH14 & -0.8 & -0.5 & 8.3 & 2.3 & 1.9 & 4.3 & 0.3 & 0.3 & 1.92 \\
\hline OH15 & -0.1 & 0.3 & 0.4 & 1.9 & 1.6 & 2.7 & 0.1 & 0.2 & 0.16 \\
\hline OH16 & 2.1 & -5.6 & 0.4 & 1.9 & 1.8 & 2.7 & 1.1 & 3.2 & 0.15 \\
\hline OH17 & -0.5 & 0.2 & 1.7 & 1.9 & 1.6 & 2.5 & 0.3 & 0.1 & 0.68 \\
\hline OH19 & -1.3 & 0.8 & -2.6 & 2.5 & 2.2 & 4.3 & 0.5 & 0.4 & 0.6 \\
\hline ОН20 & 0 & 1.2 & 2.9 & 1.8 & 1.6 & 2.5 & 0 & 0.7 & 1.18 \\
\hline OH21 & -0.8 & 0.3 & 0.2 & 1.9 & 1.5 & 2.4 & 0.4 & 0.2 & 0.07 \\
\hline OH22 & -0.8 & -0.1 & 4.6 & 2 & 1.6 & 3.1 & 0.4 & 0.1 & 1.48 \\
\hline OH23 & -0.2 & 0.7 & -2.1 & 2 & 1.6 & 2.7 & 0.1 & 0.5 & 0.8 \\
\hline OH24 & 0 & 0.8 & -0.5 & 2 & 1.7 & 2.8 & 0 & 0.4 & 0.18 \\
\hline OH25 & -0.6 & 0 & -1.1 & 2.2 & 1.8 & 3.2 & 0.3 & 0 & 0.33 \\
\hline OH26 & -2.3 & -0.4 & 2.5 & 2.3 & 2 & 4.2 & 1 & 0.2 & 0.6 \\
\hline ОН27 & -0.7 & 0.4 & 5 & 2.1 & 1.7 & 3.1 & 0.3 & 0.2 & 1.62 \\
\hline ОН 28 & 1 & 1.9 & -2.6 & 2.5 & 2.2 & 4.4 & 0.4 & 0.9 & 0.58 \\
\hline
\end{tabular}




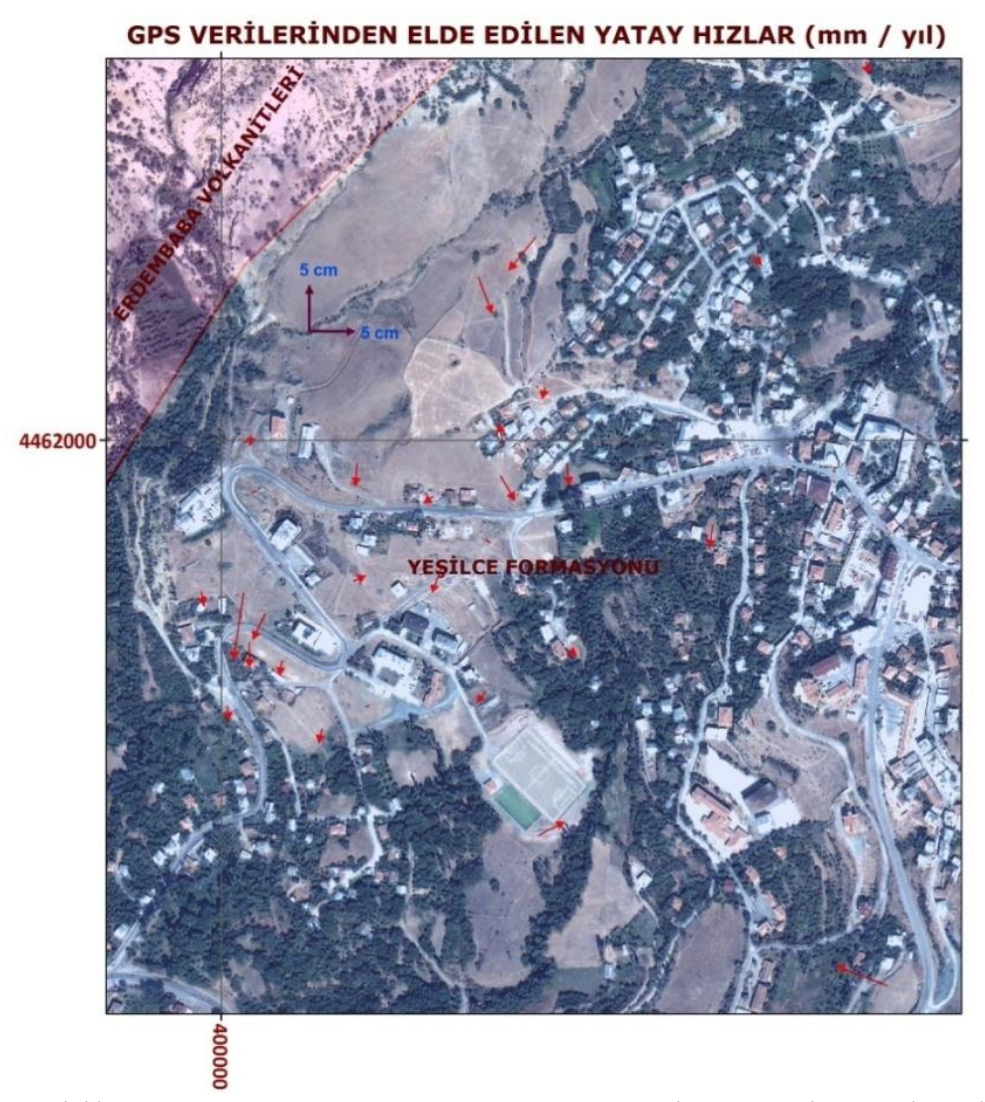

Şekil 5. 6 periyotluk GPS noktalarına ait yatay hız vektörleri

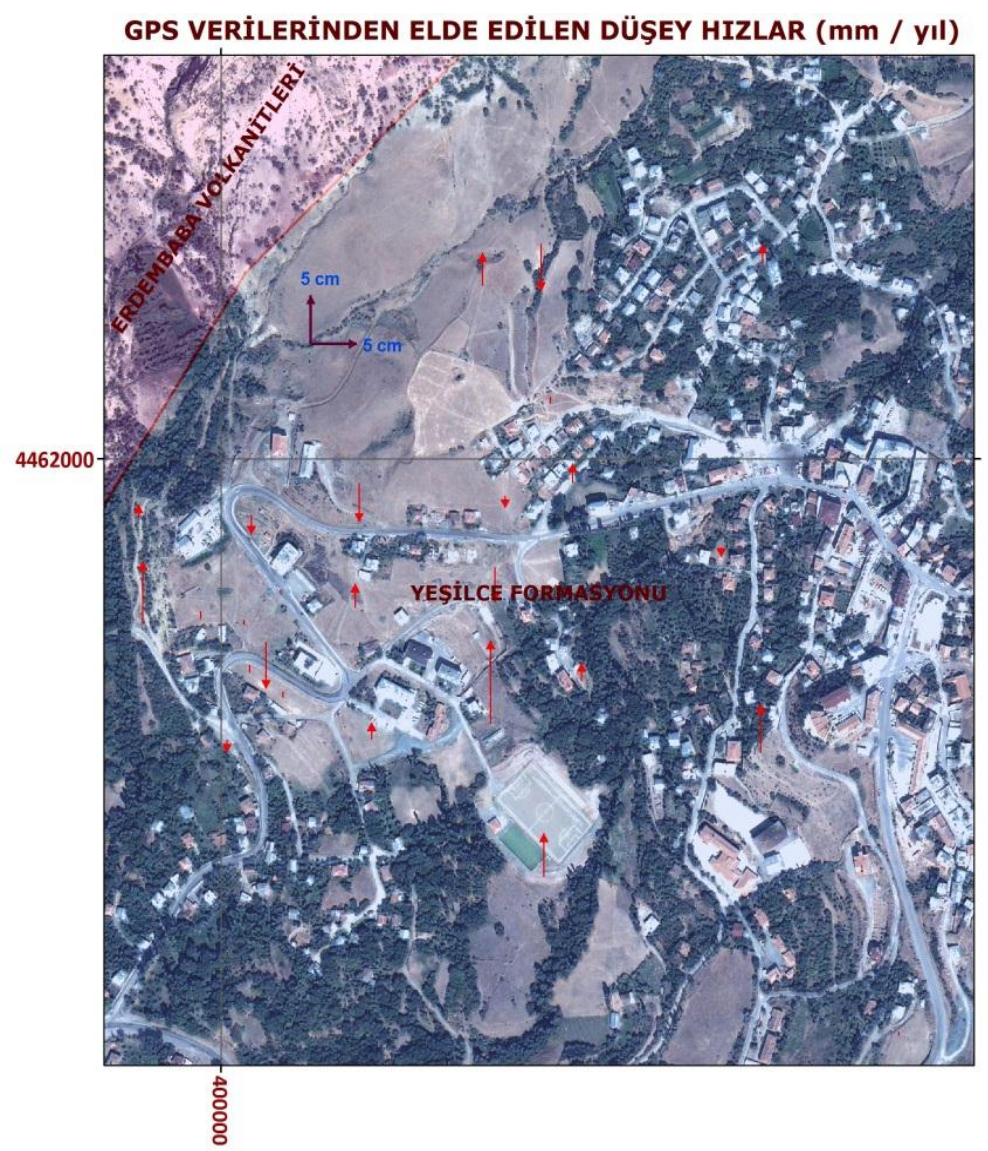

Şekil 6. 6 periyotluk GPS noktalarına ait düşey hız vektörleri 

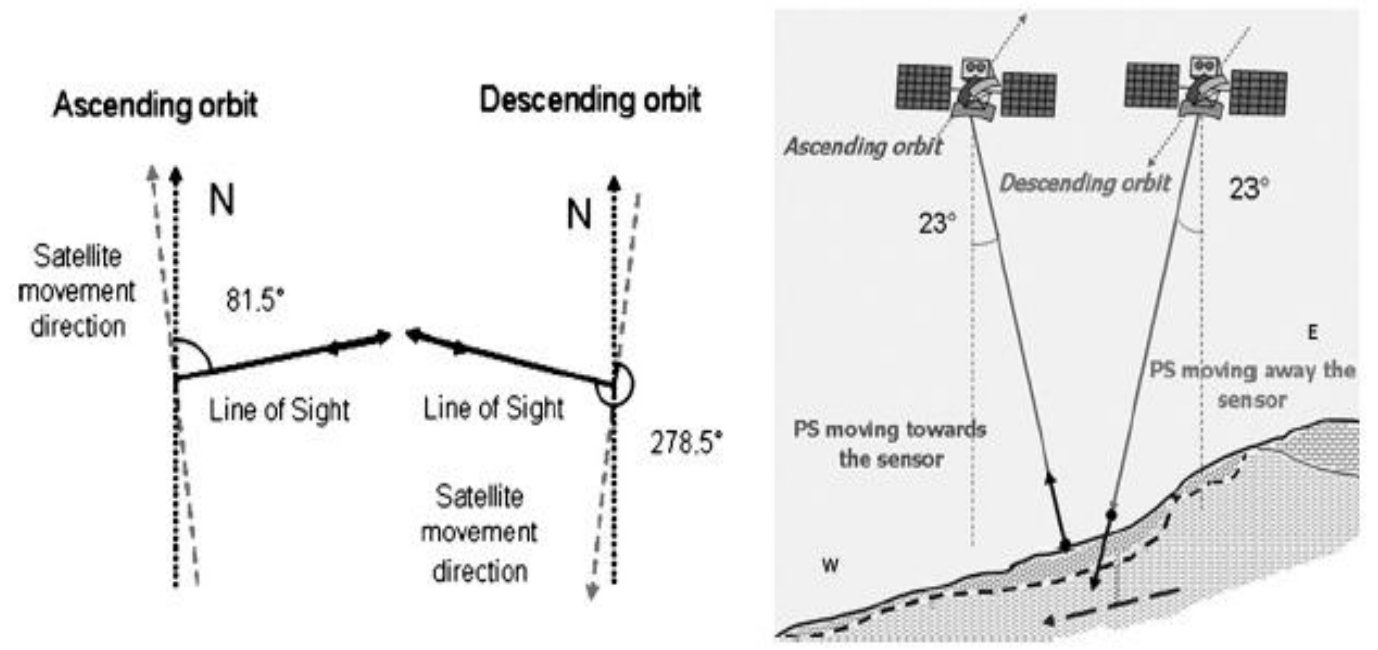

Şekil 7. PS-InSAR ölçüm prensibi

ilk olarak 443 iz numaralı uydular için STAMPS programı kullanılarak değerlendirme işlemi gerçekleştirilmiştir. Değerlendirme işleminde Koyulhisar bölgesine ait alan tüm çerçeveden heyelan sahasını da içinde barındıran bir bölge kesilerek bu bölgeye ilişkin değerlendirme gerçekleştirilmiştir.

Şekil 8'de ise PS-InSAR değerlendirmesi sonucunda elde edilen PS noktaları ve bu noktalara ait hız değerleri verilmektedir. Şekil 8 incelendiğinde özellikle daha önce meydana gelmiş olan heyelan kütlesi üzerinde uydu bakış doğrultusunda bir çökme gözlenirken, daha güneyde bulunan şehir merkezinde bir yükselme gözlenmektedir.

Değerlendirme sonuçları incelendiğinde genel olarak 1998 ve 2000 yıllarında gerçekleşen heyelanlar neticesinde oluşan heyelan kütlesi üzerinde uydu bakış doğrultusunda bir çökme gözlenmekte şehir merkezinde ise bunun tersi yönünde bir hareket yükselme ile birlikte. Bunun yanı sadece 443 iz numaralı uydu sonuçlarından yola çıkarak genel bir yorum yapmanın doğru olmayacağı düşünülmektedir. Genel yorumların gerçekleştirebilmek için 307, 443 ve 171 numaralı uydu verilerinin de değerlendirilip daha sonra LOS (Line of Sight (Uydu bakış doğrultusu) yünündeki hız değerlerinin yatay ve düşey bileşenleri ayrılarak daha detaylı incelenmesi gerekmektedir. $\mathrm{Bu}$ işlemlerde önümüzdeki 1 yıllık periyotda gerçekleştirilmesi planlanmaktadır.

Değerlendirmelerin yanı sıra Alman Uzay Ajansı ile gerçekleştirilen protokol çerçevesinde güncel uzay radar görüntülerinin de alım işlemlerine başlanmıştır. Şuana kadar İki farklı Terrasar-X uydusuna ait 7 adet görüntü alımı gerçekleştirilmiştir. Ps-InSAR değerlendirme işleminin iyi sonuçlar üretebilmesi için en az on iki adet uydu görüntüsüne ihtiyaç duyulduğundan henüz Terrasar-X verileri değerlendirilememiştir. Terrasar-X verilerinin değerlendirilme işlemlerine veri sayısının on ikiyi aşmasının ardından ancak projenin ikinci yılında başlanabilecektir. 


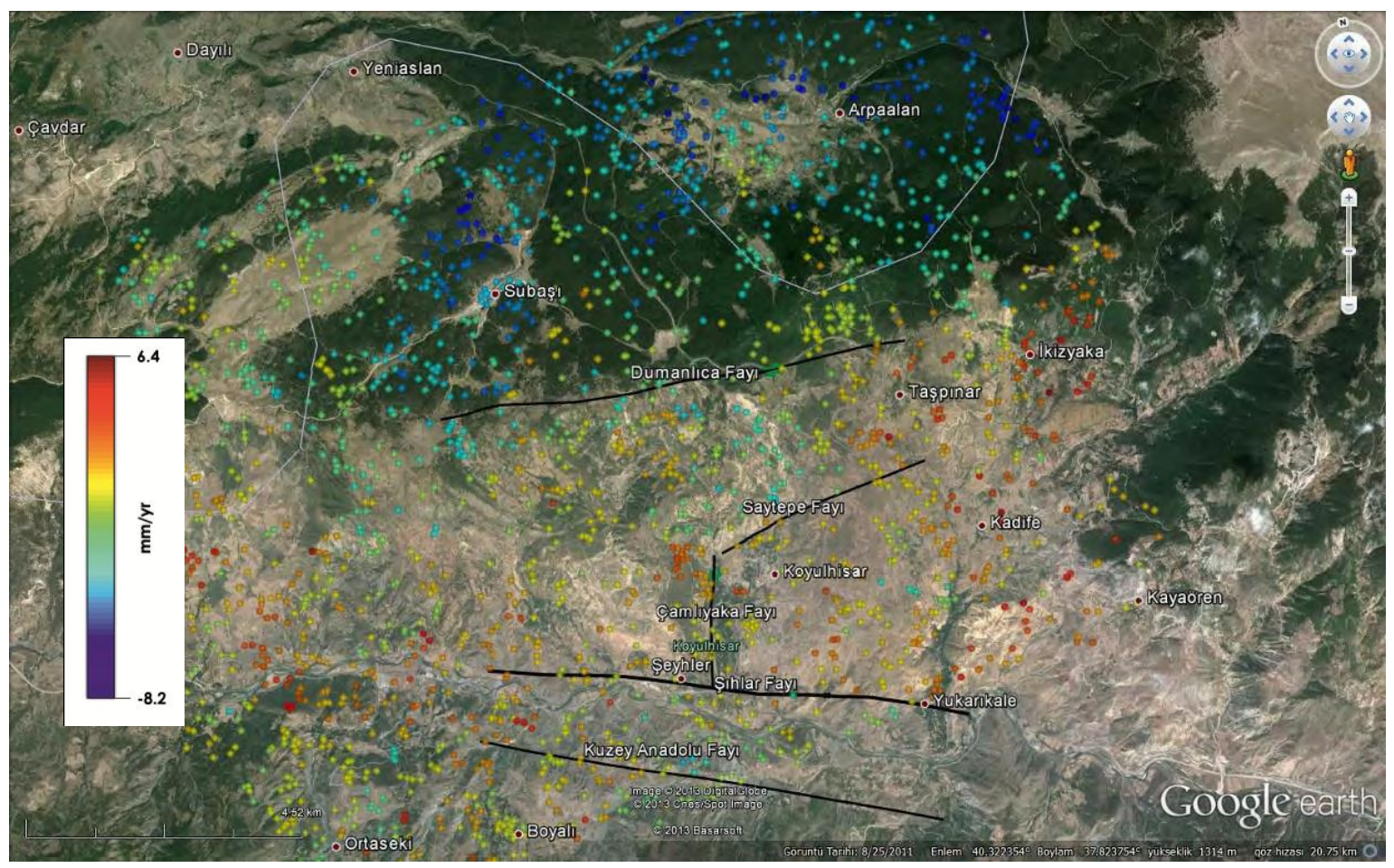

Şekil 8. 2006-2009 y1lları arası 443 iz numaralı uydu verilerinden elde edilen PS noktaları ve bu noktalara ait hız değerleri

\section{Sonuçlar}

Sonuç olarak projenin ilk bir buçuk yıllık k1sminda heyelan sahasinda 55 adet GPS noktası tesis edilmiş olup bu noktalarda toplam 6 periyot GPS gözlemi gerçekleştirilmiş ve bu veriler değerlendirilmiştir. Değerlendirme sonucunda elde edilen koordinat değişim değerleri yardımı ile GPS noktalarına ait hız değerleri kestirilmiştir. Elde edilen hız değerleri Kinematik Kalman Filtreleme tekniği kullanılarak elde edilmiştir. Fakat bu modelle GPS noktalarındaki dış kuvvetlere (yağış, sıcaklık, yer altı suyu v.b. değişimleri) bağlı değişimler modellenememektedir. Bu amaçla mevsimsel etkinin görülebileceği en az iki senelik veri seti tamamlanmasının ardından GPS noktalarına kayma miktarları Dinamik Kalman Filtreleme Yöntemi kullanılarak değerlendirilecektir. Böylelikle kayma miktarları ile dış kuvvetler arasındaki ilişki belirlenebilecektir.

Bilindiği üzere GPS den sonuçlarında üç boyutlu yatay ve düssey (north, east, up) hız değerleri elde edilirken, PS-InSAR sonuçlarında sadece uydu bakış doğrultusundaki (Line of sight (LOS)) hız değerleri elde edilmektedir. Bu yüzden bu iki sistemle elde edilen hız değerleri farklılık içermektedir. $\mathrm{Bu}$ iki sistemden elde edilen sonuçların analizini gerçekleştirebilmek için üç aşamalı bir analiz yazılımının geliştirilmesi planlanmaktadır. Bu plan dâhilinde ilk olarak hız değerlerindeki farklılığı ortadan kaldırabilmek için iki farklı yöntemle elde edilen hiz değerlerinin tek bir sistemde ifade edilesi gerekmektedir. GPS den elde edilen üç boyutlu hız değerleri tek boyutlu LOS hız değerlerine dönüştürülerek hem GPS hem de PS-InSAR sonuçlarının karşılaştırılması sağlanacaktır.

Karşılaştırma işleminin ikinci aşamasında ise iki farklı sistemden (GPS ve PS-InSAR) elde edilen LOS hiz değerlerine göre enterpolasyon yöntemi kullanılarak çalışma bölgesinin $0.001^{\circ}$ aralıklarla LOS değerleri hesaplanacaktır. Son aşamada ise grid noktalarına ait her iki sistemden elde edilen LOS değerleri arasındaki korelasyon değerleri hesaplanarak sonuçlar yorumlanacaktır.

\section{Teşekkür}

Bu çalışma TUBİTAK 111 Y111 ve CUBAP M-468 nolu projeler ile desteklenmektedir. $\mathrm{Bu}$ proje kapsamında BERNESE 5.0 programı TUBİTAK- 
MAM ile yapılan protokol çerçevesinde kullanılmıştır. Çalıma süresince Google Earth uydu görüntülerinden faydalanılmıştır. Radar görüntüleri Avrupa Uzay Ajansı (ESA) ve Alman Uzay Ajansı (DLR) ile yapılan protokol kapsamında elde edilerek kullanılmıştır.

\section{Kaynakça}

Acar, M., Ozludemir, T., Erol, S., Celik, R.N. \& Ayan, T. 2008. Kinematic landslide monitoring with Kalman filtering. Natural Hazards and Earth System Sciences 8, 213221.

Bamler, R. and Hartl, P., 1998. Synthetic Aperture Radar Interferometry, Inverse Problems 14, R1-R54.

Brunner, F.K. ve Welsch, W.M., 1994. Effects of the Troposphere on GPS Measurements, GPS World, 4:4251.

Brunner, F. K., 1997. Continuous Monitoring of Deformation Using The Global Positioning System, $\mathrm{AvH}$ Magazine, 69, 29-38.

Bayrak T., 2003. Heyelanlar için Bir Dinamik Deformasyon ve Bir Dinamik Hareket Yüzeyi Modelinin Olusturulmas1, Doktora Tezi, Karadeniz Teknik Üniversitesi Fen Bilimleri Enstitüsü, Trabzon, Ocak.

Bayrak, T. 2009. Determining the influence of rainfall on the activity of Kulugun landslide. Fresenius

Environmental Bulletin, 18, 7b.

Coe J.A., Ellis W.L., Godt J.W. , Savage W.Z., Savage J.E., Michael J.A.,Kibler J.D., Powers P.S., Lidke D.J., Debray S. , 2003. Seasonal movement of the Slumgullion landslide determined from Global Positioning System surveys and field instrumentation,July 1998-March 2002,Engineering Geology 68 (2003) 67-101.
Colesanti, C., Ferretti, A., Prati, C., ve Rocca F., 2003a. Monitoring landslides and tectonic motions with the Permanent Scatterers Technique. Engineering Geology 68 (2003) 3 14.

Dercourt, J., 2000. Apport du GPS au Suivi en Continu des Mouvements de Terrrain:Applicatio au GlissementCoulee de Super-Sauze (Alpes-deHaute-Provence,France), Earth and Planetary Sciences, 331, 175-182.

Farina, P., Colombo, D., Fumagalli, A.., Marks, F., Moretti, S., 2006. Permanent scatterers for landslide investigations: outcomes from the ESA-SLAM Project, Engineering Geology 88, 200-217.

Ferretti A., Prati C., ve Rocca F., 2001. "Permanent Scatterers in SAR Interferometry," IEEE Trans. on Geoscience and Remote Sensing, Vol. 39, no. 1, pp. 8-20.

Gens, R. ve Vangenderen, J.L., 1996. SAR interferometry - issues, techniques, applications. International Journal of Remote Sensing, 17, 1803-1835.

Gens, R., 1998. Quality assessment of SAR interferometric data, $\mathrm{PhD}$ Thesis, Universtiy of Hannover, Hannover, Germany.

Gili, J. A., Corominas, J., Rius, J., 2000. Using Global Positioning System Techniques in Landslide Monitoring, Engineering Geology, 55, 167-192.

Hastaoglu K.O., 2009. GPS Hizlı Statik Yöntem ile Heyelanların izlenebilirliğinin Arastırılması: Sivas Koyulhisar Heyelanı Örnegi,Doktora Tezi, Yıldız Teknik Üniversitesi Fen Bilimleri Enstitüsü, İstanbul 
Madsen, S. N., Zebker, H. A. ve Martin, J., 1993. "Topographic Mapping Using Radar Interferometry: Processing Techniques", IEEE Transactions on Geoscience and Remote Sensing, Vol.31, pages 246-256.

Malet, J. P., Maquaire, O., Calais, E., 2002. The Use of Global Positioning System Techniques for The

Continuous Monitoring of Landslides: Application to Yhe Super-Sauze Earthflow (Alpesde-Haute-Provence, France), Geomorphology, 43, 33-54.

Massonnet, D.ve Feigl, K. L., 1998. Radar Interferometry and its Application to Changes in the Earth Surface, Reviews of Geophysics Vol. 36, Number 4, November 1998, pages 441-500.

Meisina, C., Zucca, F., Fosatti, D., Cerıani, M., ve Allievi, J., 2006. Ground deformation monitoring by using the Permanent Scatterers Technique: The example of the Oltrepo Pavese (Lombardia, Italy). Engineering Geology 88 240-25.

Moss, J. L., McGuire, W. J., Page, D., 1999. Ground Deformation of a Potential Landslide at La Palma, Canary Islands, Journal of Volconology and Geothermal Research, 94, 251256.

Peyret M., Djamour Y., Rizza M., Ritz J.-F, ,Hurtrez J.-E., Goudarzi M.A., Nankali H. , Chéry J., Le Dortz K., Uri F., 2008. Monitoring of the large slow Kahrod landslide in Alborz mountain range (Iran) by GPS and SAR interferometry, Engineering Geology 100, 131141.

Rosen, P. A., Hensley, S., Joughin, I.R., Li, F.K., Madsen, S.N., Rodriguez, E. ve Goldstein, R. M., 2000.

Synthetic aperture radar interferometry", Proceedings of IEEE, Vol. 88, pages 333382.

Sendir, H. and Yilmaz, I., 2002. "Structural, geomorphological and geomechanical aspects of the Koyulhisar landslides in the North Anatolian Fault Zone (SivasTurkey)". Environmental Geology, 42 (1), 52-60.

Sousa J.J., Ruiz A.M., Hanssen R.F., Bastos L, Gil A.J., Galindo-Zaldívar J., Sanz de Galdeano C., 2010.

PS-InSAR processing methodologies in the detection of .eld surface deformation Study of the Granada basin (Central Betic Cordilleras, southern Spain), Journal of Geodynamics 49 181189.

Toprak, V., 1988. Neotectonic characteristics of the North Anatolian Fault Zone betwen Koyulhisarand Suşehri (NE Turkey), METU Jr. Pure and Applied Sciences, 21, 1-3, 155-168.

Yalçınkaya, M. \& Bayrak, T. 2005. Comparison of static, kinematic and dynamic geodetic deformation models for Kutlugün landslide in Northeastern Turkey. Natural Hazards 34, 91110. 